\title{
IKERLANAK
}

\section{LOWNDES AND LOCKE ON THE VALUE OF MONEY}

by

Kepa M. Ormazabal

2007

Working Paper Series: IL. 29/07

Departamento de Fundamentos del Análisis Económico I

Ekonomi Analisiaren Oinarriak I Saila

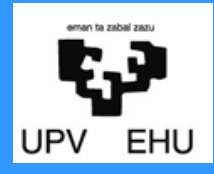

University of the Basque Country 


\title{
LOWNDES AND LOCKE ON THE VALUE OF MONEY
}

\begin{abstract}
In this paper I analyze the monetary theories underlying the arguments that Locke and Lowndes directed against each other during their discussions around the Great Recoinage of 1696. My primary place of interest is the theory that Marx calls "the theory of the nominal standard of money", which is the theory that the monetary names stand for definite quantities of value, so that the unit of money is a unit of value. I argue that Lowndes appealed to this theory and that the criticism of it offered by Locke is fundamentally correct, in spite of which Lowndes' language and ideas can be very often found in current discussions about monetary problems. In the course of this theoretical investigation, I have come across the critical commentaries of Steuart and Marx, which are not paid the attention they deserve in the standard literature. Marx commentary is of special interest because it contains a solid theoretical explanation of the concepts appealed to in the debate and puts it in a very interesting practical perspective.
\end{abstract}

This paper was presented at the $11^{\text {th }}$ Annual Conference of the European Society for the History of Economic Thought (ESHET). I greatly benefited from the debate that followed my presentation. In particular, I have to thank the interesting comments of Seiichiro Ito and Ludovic Desmedt. I am also indebted to my Department fellow Javier Arin for his critical formulations on monetary problems.

Key words: monetary theory; value of money, English monetary history; history of English banking

JEL classification: B11, E42, E52

Kepa Ormazabal

Department of Economic Theory I

University of the Basque Country

Lehendakari Agirre etorbidea 83

E-48015 Bilbo, Bizkaia

Spain

Phone: 34-94-6013772

Fax: 34-94-6013891

e-mail: kepa.ormazabal@ehu.es 


\section{Introduction}

By 1696, the English silver currency had lost much of its metal content, because of the combined effect of intensive usage and clipping. Although this fact was widely known, the role played by those coins in payments was so prominent that they remained in circulation. The loss of silver of the coins and the uncertainty about the actual content of each particular coin gave rise, as can be logically expected, to abundant and continuous litigations. In 1696, and after a long debate, the English Treasury finally acted to restore monetary order and proceeded to recoin the English stock of silver, in what is known as the Great Recoinage of 1696. A central question in the debates was the mint-parity at which the recoinage was to be carried out. The price of silver bullion at London had been consistently above the official mint-parity for years, and this fact could not be ignored. There were, basically, two answers to this central question: first, to set the current market price of silver at London as the new mint-parity; secondly, to keep the current official mint-parity unchanged, regardless the continued excess of the market price of silver over the mint-parity.

The main advocate of the first proposal, which thus involved a debasement of the silver coins in accordance to the high price of bullion, was Lowndes. His plan of monetary reform was to recoin all the silver in England according to the high price of silver bullion that had prevailed at London for years. In practical terms, Lowndes' plan was to diminish the silver content of all English coins by $20 \%$. His plan of recoinage was intrinsically associated, therefore, to a proposal of debasement according to the market price of silver bullion. Lowndes held that such a recoinage plus debasement would not hurt the interest of anyone, because everybody would get the same money as before the recoinage, even though, truly, everybody would get $20 \%$ less silver than before. After all, as experience had amply shown, the ability of coins to discharge debts depends on its face value, not on its metal content.

Locke was the main advocate of the second plan of monetary reform, which consisted in recoining the English stock of silver according to the old official mintparity. Locke, thus, disputed not the desirability of a recoinage, but the desirability of the debasement that Lowndes was putting forwards. Locke replied to Lowndes that any debasement involves a fraud to the landlords and money lenders; also, of course, the debasement according to the higher market price of silver bullion. According to Locke, 
less silver necessarily implies less money; in consequence, he opposed the thesis of Lowndes' that the debasement would not have any re-distributive consequences and held that it certainly would.

In the end, Locke prevailed over Lowndes and, in the Great Recoinage of 1696, the English stock of silver was recoined according to the old official mint-parity rather than at the higher price of silver bullion that had prevailed at London during the war. This paper concentrates on the theoretical issues at stake. The political and institutional context of the debate has received an excellent treatment by Desmedt (Desmedt, 2007a) which also contains a lot of highly valuable financial information. Having said that, let us start the theoretical examination on the debate by the ideas of Lowndes.

\section{Lowndes' Proposal of Monetary Reform}

The proposal of Lowndes in this document is to recoin all the English silver at a mint-parity $1 / 5$ higher that the official mint-parity current before 1695 , which amounts to diminishing the silver content of English coins by $20 \%$ at the same time that the names of the silver coins are kept unchanged. Lowndes advocated this debasement on the basis that the market price of silver bullion at London was consistently $20 \%$ higher than the official mint-parity of silver coins. This shows, said Lowndes, that the value of silver has risen. Lowndes, thus, attributed the excess of the market price of bullion over the mint-parity to the rise in the value of silver.

What evil could be derived from the acknowledgement of the fact that now an ounce of silver is worth five instead of four shillings? asks Lowndes. The continued high price of silver bullion in the free market shows, according to Lowndes, that the value of silver in England has risen. That the shilling or nominal price of the silver bullion has risen by $20 \%$ means that the amount of silver required to purchase a shilling has fallen by $20 \%$. That less silver is required to purchase an English shilling means that the value of silver in relation to the English shilling has risen. The market is showing that the value of the silver contained in the English silver coins has risen by $20 \%$. If we want a stable measure of value, the action that logic requires is to reduce by $20 \%$ the silver content of the coins. If the silver content of the silver coins is reduced by the same 
proportion as that by which the value of the silver with which they are made rises, we have a constant unit of value and, therefore, a currency in good order.

For Lowndes, the diminution of the amount of silver contained in the coins does not alter in the least the purchasing power of those coins, because the ability of the coins to redeem debts depends only on the mark stamped upon them, that is, on the name they bear. A crown is always a crown, and a shilling is always a shilling, regardless of the amount of silver contained in the crown coins. As long as one receives the same amount of shillings, or of crown coins, one is receiving the same money. This means that the landlords will not be defrauded of any wealth because they will receive as rent the same number of coins or of shillings after and before the debasement; that is to say, they will receive the same amount of money as before the debasement because they will receive the same amount of shillings. It is true that the landlords will not receive the same amount of silver as before the debasement, but they will receive the same amount of money, which is what the debate is all about, and this is true because the name of the money they receive stays the same. Silver can rise or fall in value, that is, in value in terms of shillings; the fact in 1695 is that it has risen. Accordingly, everything costs less silver, which means that the loss in content of the coins implied by the debasement is exactly compensated by the rise in the lower amount of silver they contain. As a consequence of these two offsetting effects, the landlords and the creditors will receive the same value and, therefore, the same money in payment. The debasement of the silver currency in accordance with the high price of silver does not have any redistributive effect and does not defraud anybody of his wealth.

One could even take one step further and contend that, if the silver coins are not debased when silver rises in value, there is a hidden unjust premium for the landlords and creditors, as they get more money than that owed to them. Without a debasement in accordance with the high price of silver, the landlords and the creditors would get the same amount of silver, but, as the value of that silver has risen and the content of the coins has not been reduced by the same proportion, they get value in excess of the value owed to them, which means that they get money in excess of the money owed to them. I have not seen this objection raised by any of the two parties of this debate, but it logically follows from the arguments presented in the discussion. 
Lowndes insists that the only purpose of the debasement he proposes is to acknowledge the fact that the value of silver in England has risen. This means that he would accept that there would be room for accusations of fraud if the plan contemplated a recoinage according to a new mint-parity different from the current market price of silver, but this is not the case. The continuous excess of the price of silver bullion over the official mint-parity shows that silver has risen in value. The purpose of the plan is to keep constant the quantity of value named by the English monetary names. Lowndes is therefore saying quite clearly that the monetary names are names of quantities of value, and not of quantities of silver.

The debasement of the English currency does not modify the amount of money received by anyone because it does not change the nominal price of anything. Silver rises in value against the commodities, but also against the monetary names, which means that, as less silver is needed to purchase everything, nominal and relative prices remain the same with a debasement according to the high price of silver. Everybody goes on paying the same money for the same things if the silver content is reduced according to the rise in the value of silver. If a loaf of bread costs one shilling, one shilling will always buy a loaf of bread, because the amount of silver that purchases the shilling itself falls by the same proportion. Why keep heavy shillings in circulation when debts can be discharged with light shillings owing to the rise in the value of silver? would ask Lowndes. Those who own the few heavy shillings that might continue in existence will certainly find it to their advantage to melt them and recoin them into more shillings. This is true, but represents no injustice, as it is a simple reflection of the fact that the value of silver has risen.

Lowndes is saying that "shilling" is the name of a definite quantity of value; say, of the value of a loaf of bread or of a pint of milk. The amount of silver that the shilling coin may contain does not affect the meaning of the monetary name "shilling". A shilling will always be a shilling, no matter what its metallic content might be.

The rise in the value of silver is but the other side of the coin of a corresponding fall in the value of the shilling. Before the debasement, it was necessary to give out $1 / 4$ of an ounce of silver in exchange for a shilling; now, after the debasement, only $1 / 5$ of an ounce of silver purchases a shilling. The rise in the value of 
silver implies, accordingly, an equi-proportional fall in the value of the shilling against silver, not any rise in the shilling prices of commodities, but only in their silver prices.

One could say that, for Lowndes, the main effect of a debasement in accordance with the market price of silver would be a more efficient use of the English stock of silver, as the same amount of silver will perform more payments than before. In this sense, the debasement will enhance the supply of English money. This is important because Lowndes held that this supply was insufficient. For Lowndes, the high price of bullion shows that the value of silver in England and, therefore, the money contained in the English stock of silver had grown beyond the quantity established by legal conventions; first of all, by the legal mint-parity. Why cut the supply of money, of silver coins, at a time when the market shows that silver contains more value? The debasement of the English silver coins according to the market price of silver bullion would multiply the English money supply, but, as the quantity of money would rise by the same proportion in everybody's hands, monetary relations, which basically means relative prices, would stay the same. Everybody would continue to get the same number of cons of the same denomination as before the debasement and, therefore, the same money. The only change, which is irrelevant for the value of money, is that the silver content of each English silver coin will be lower than before.

Lowndes could be read as claiming that the refusal to debase the English silver coins in accordance with the high market price of silver was a waste of silver, an inefficient monetary arrangement that failed to make the most of the silver existing in England, an unfounded restriction of the supply of English money. The refusal to debase the English silver coins according to the high market price of silver bullion involves a refusal to expand the supply of money that just makes payments more difficult and more expensive than they should be otherwise. Because of the enhanced value of silver, there is more money in each silver coin when the value of silver rises (that is, when the market price of silver bullion rises above the official mint-parity). The rise in the value of silver logically calls for the reduction of the amount of silver that serves as standard of price, so as to keep constant the value that serves as standard of price. This means that, for Lowndes, the standard or unit of price is a unit of value; this is the theory that Marx labels "theory of the nominal standard of money". We can see that Lowndes accepted this theory. 


\section{Locke's Refutation of Lowndes}

Locke agreed with Lowndes on the necessity of recoining the English stock of silver in order to restore monetary stability, but frontally disagreed with on the matter of the $20 \%$ debasement of the silver coins. Locke held against Lowndes that the excess of the market price of silver over the official mint-parity was not the consequence of anything like a "rise in the value of silver", but simply the measure of the common estimation of the average loss of silver of the English coins. There was, therefore, no need to debase the coins because of any revaluation of silver and, if such debasement were carried out, it would provoke a re-distribution of wealth, as against Lowndes.

For Locke, the excess of the market price of silver over the mint-parity, even if persistent, does not justify a debasement and, in particular, does not justify a debasement in accordance with the high price of bullion. The main effect of such a debasement would b e distributional and Locke wants to make clear that no debasement is neutral for the distribution of wealth. In particular, the debasement proposed by Lowndes involved a fraud to the class of landlords and to the class of money lenders. These classes would be defrauded of $20 \%$ of their wealth as a consequence of the reduction of the silver content of the coins by $20 \%$, because, in receiving $20 \%$ less silver they would receive $20 \%$ less money. The recoinage proposed by Lowndes involved, thus, a $20 \%$ diminution in the wealth of landlords and money lenders. This loss had its counterpart in an equivalent gain for those who, at the time of the debasement, happened to possess unworn coins. Though it is true that the English silver should be recoined because of the bad state of the English coins, it is no less true that English silver should be recoined according to the old mint-parity, not according to the market price of silver bullion. Otherwise, the recoinage would involve an unjust redistribution of wealth.

In order to argue that the excess of the market price of silver does not call for any equivalent debasement of the silver coins, Locke directs his attacks against the theoretical foundations of Lowndes' apology of this plan. Basically, Locke argues that the explanation of the excess of the market price of silver over the mint-parity as the consequence of a rise in the value of silver (in the value of the standard of price) is nonsensical. Accordingly, Locke states against Lowndes that the monetary names are 
not names of definite quantities of value, but of definite quantities of a particular commodity, such as, in the case at hand, silver.

"Mr. Lowndes proposes, that our Money should be raised (as it is called) one fifth: that is, That all our present denominations of Money, as Penny, Shilling, Half-crown, Crown, \&c. should each have One fifth less Silver in it, or be answered with Coin of One fifth less value.” (Locke, 1691)

\section{However:}

"If all the Species of Money, be, as 'tis call'd raised by making each of them to have One twentieth less of Silver in them than formerly; and so your whole Money be lighter than it was: These following will be some of the consequences of it.

1. It will rob all Creditors of One twentieth (or 5 per Cent.) of their Debts, and all Landlords One twentieth of their quit Rents for ever; and in all other Rents as far as their former Contracts reach, of 5 per Cent. of their yearly Income; and this without any advantage to the Debtor, or Farmer." (Locke, 1691)

The debtors do not gain what the creditors lose, says Locke. Steuart will afterwards reject this thesis of Locke, as we shall presently see. The creditors lose $5 \%$ because they are given 5\% less silver and this implies, for Locke, that they receive 5\% less money. Why do not the debtors gain this 5\% according to Locke? Who gets it? Let me note how Locke takes it for granted that a debasement implies a zero-sum game, in which the loss of one party must be the gain of another. Let us return to the question: who gains what the creditors and landlords lose? The answer turns out to rest on the answer to the question as to whether or not the general price level will rise by $5 \%$. If prices stay the same after the debasement, the debtor receives the same amount of coins as before, but 5\% less silver. As nominal magnitudes are concerned, the position of the money lender or the landlord, without inflation, remains unaltered; as real magnitudes are concerned, he receives less silver. The question is whether "less silver" implies "less money".

If the general price level rose by $5 \%$ after the debasement and the farmer sold his produce at a price 5\% higher, he would receive 5\% more coins, but, as these coins are 5\% lighter, he would get the same silver as before. "In nomine" he gets 5\% more but "in re" he gets the same silver as before. As all nominal prices have moved up in the same direction and proportion of 5\%, relative nominal prices remain unchanged, and the 
debasement has not altered relative prices -therefore, the interest of the farmer, "in re", remains unchanged. Who then gains what the creditors lose?

"For Money having been Lent, and Leases and other Bargains made, when Money was of the same Weight and Fineness that it is now, upon Confidence that under the same names of Pounds, Shillings and Pence, they should receive the same value, (i.e. the same quantity of Silver) by giving the denomination now to less quantities of Silver by One twentieth, you take from them 5 per Cent. of their due.” (Locke, 1691)

Locke ties here "money" to "value": there is the same quantity of money where there is the same value. But this is precisely the fundamental error that he denounces in Lowndes! Indeed, as we shall see in the course of this paper, Locke did not coherently stick to the thesis that he so much stresses against Lowndes that the monetary names are names of determinate quantities of a particular commodity and not of determinate quantities of value. The standard literature does not note this internal inconsistency in the writings of Locke. In my opinion, Locke strikes the right note when he states this thesis against Lowndes, a thesis on the value of money that Lowndes never held. The reply of Locke to Lowndes could be summed up saying that two ounces of silver will always represent double the value of one ounce of silver, regardless of the marks stamped upon the ounces of silver might be. There are abundant passages where Locke explicitly holds this view; for instance, in his "Further Considerations" he notes:

"Silver is the Measure of Commerce by its quantity, which is the Measure also of its intrinsick value. If one grain of Silver has an intrinsick value in it, two grains of Silver have double that intinsick value, and three grains treble, and so on proportionably.” (Locke, 1697)

\section{Accordingly:}

"When Men go to Market to buy any other Commodities with their new, but lighter Money, they will find $20 \mathrm{~s}$. of their new Money will buy no more of any Commodity than 19 would before. For it not being the denomination but the quantity of Silver, that gives the value to any Coin, 19 Grains or parts of Silver, however denominated or marked, will no more be worth, or pass for, or buy so much of any other Commodity as 20 Grains of Silver will, than 19 s. will pass for 20 s.” (Locke, 1691)

This means that the general price level will rise by $5 \%$ if the silver content of the silver coins is reduced by $5 \%$. If the farmer (who, here, plays the role of debtor) goes on receiving in payment for his corn the same amount of coins as before, he is losing 5\% in silver and, therefore, in money, says Locke, which means that he joins his 
creditor on the losers' side of the economy, as the creditor gets 5\% less silver when he receives the same amount of coins after the debasement and, therefore, $5 \%$ less money. In more modern words, the debasement expropriates the banker and the capitalist of 5\% of their "wealth". However, we do not know yet who gets this wealth.

"For 'tis Silver and not Names that pay Debts and purchase Commodities." (Locke, 1691)

This is a straight-forward rejection of the theory of the nominal standard of money. By the way, this carries the implication that no money is created by reducing the metallic content of the coins.

For the sake of clarity, I would like to explicitly note that the relation between a monetary name and its definition is not a value relation. Lowndes views the silver coins as an imperfect form of inconvertible paper money, the ability of which to discharge debts depends on what is written rather than on the value of the stuff upon which the written is written. On that account, the actual metallic content of the silver coins is irrelevant for the determination of their purchasing power, and paper is a more developed incarnation of the same idea of supplanting the precious metals in circulation in order to reduce "transaction costs". At the same time, it is to be stressed that the relation between the monetary names and silver is not one of value, but of convention. When the mint-parity is changed, no value is changed thereby; the only thing changed is the standard of price, but in no way the value of anything; in particular, not the value of the standard of price. The determination of a mint-parity is not any determination of value whatsoever; accordingly, a change in mint-parity does not involve any change in the value of anything, nor is it needed to reflect the change in the value of anything; it just represents a change in the quantity of the particular commodity that serves as standard of price. Locke makes an interesting comment in the course of his refutation of Lowndes' plan of this point.

“His fifth Head p. 74. [KO: Locke refers to the text of Lowndes' proposal] is to answer those, who hold, that by the lessening our Money one fifth, all People who are to receive Money upon Contracts already made, will be defrauded of 20 per Cent. of their due: And thus all Men will lose one fifth of their settled Revenues, and all men that have lent Money one fifth of their Principal and Use. To remove this Objection, Mr. Lowndes says, that Silver in England is grown scarce, and consequently dearer, and so is of higher price." (Locke, 1697) 
Silver has risen in value in England because it has become scarcer, says Lowndes. This is why the market price of bullion consistently remains over the mintparity. The revaluation of silver implies that landlords and creditors will receive the same real amount of money after the debasement when they receive an unchanged amount of coins. They will receive the same real amount of money because they will receive the same nominal amount of money, and money circulates according to its name, not according to its metal content. The landlords and money lenders get the same money because they get the same value, even though it is true that they get less silver. The lower silver content of the new lighter coins is exactly offset by the increased value of silver. The landlords and money lenders receive the same value and, therefore, the same money under his plan, says Lowndes. Here is Locke's reply to this argument of Lowndes':

"Let us grant for the present, that [silver] is of higher price (which how he makes out I shall examine by and by.) This, if it were so, ought not to annul any Man's Bargain, nor make him receive less in quantity than he lent. He was to receive again the same Summ, and the Publick Authority was Guarantee that the same Summ should have the same quantity of Silver under the same Denomination. And the reason is plain, why in justice he ought to have the same quantity of Silver again, notwithstanding any pretended rise of its value." (Locke, 1697)

The contract was made for silver, not for value, replies Locke to Lowndes. One cannot give nor take value, but something that has value; in England, silver. Money is silver, and the unit of money is a particular amount of silver set by convention. The monetary names name determinate quantities of silver, not of value. Value as such cannot be counted; nothing is value as such, but something that has value. That something that has value. This means that the purest expression of value we can aim at is money, but money still is and will always be a particular commodity, a particular something that is not value but that has value. Contracts are made for money; in the English case, where silver has been conventionally chosen as money, contracts are silver, not for a name, nor for the value of an ounce of silver, and less for value in general.

Locke is here denying the thesis of Lowndes that "shilling" is the name of a quantity of value. His view against Lowndes is that "shilling" is the name of a definite quantity of silver. If silver is chosen as the standard of price, one cannot ask about the value of silver (in general, about the value of the standard of price), because that would 
amount to asking about the price of silver, which is the value of silver in terms of silver. It would amount to asking about the value of money in terms of money. Exchange value, being a relation among things, is not any of the things related. To choose silver as money is to choose silver as the standard of price, answers Locke to Lowndes, from which it follows that an equal quantity of money means an equal quantity of silver, no matter what the value of silver in relation to the rest of the commodities might be. Therefore, the landlords and the money lenders get 20\% less money when they get $20 \%$ less silver under Lowndes' plan of debasement according to the high market price of silver bullion.

One may come to the rescue of Lowndes by replying to Locke that the matter of contract is value, not money, or that it is money in so far as money stands for value, that giving money is just a means of giving value. That contracts are not made for value is plain; that they were made for "shillings" and the like at the time of Lowndes and Locke is plain too, but the question is all about the relationship between silver and money and between money and value. According to Lowndes, 1 light shilling represents the same money as 1 heavy shilling as long as the stamp upon the coin remains the same. According to Locke, by contrast, 1 light shilling represents less money than 1 heavy shilling because it contains less silver.

Indeed, if one consistently follows the basic idea of Lowndes, one is led to say that there is no limit to the reduction in the metallic content of the English silver coins. The less valuable the stuff of which money is made, the better, for the lower the cost of the means of payment. Locke does not question that a less expensive means of payment involves a lower cost; his point is directed, rather, to the view that the introduction of monetary names suppresses the role of silver as measure of value. From the perspective of Locke, one could say that Lowndes is right to imply that silver could be substituted for cheaper representatives in actual payments, but wrong to say that this possibility breaks the link between silver and money, that is, that the replacement of silver by tokens in circulation puts a quantity of value as standard of price instead of a quantity of silver. As I see it, Locke is right to reply to Lowndes that 1 ounce of silver, whatever the name given to it, will always represent the same amount of money, regardless of the variations of the value of silver in relation to the rest of the commodities. For Locke, 
contrary to Lowndes, "shilling" is the name of a definite quantity of silver, of some particular commodity; never of a quantity of value.

"Cacao Nuts were the Money of a part of America, when we first came thither. Suppose then you had lent me last Year 300, or fifteen-score Cacao Nuts, to be repaid this Year: Would you be satisfied and think your self paid your due, if I should tell you, Cacao Nuts were scarce this Year, and that fourscore were of as much value this year as an hundred the last; and that therefore you were well and fully paid if I restored to you only 240 for the 300 I borrow'd? Would you not think your self defrauded of one fifth of your Right by such a payment? nor would it make any amends for this to Justice, or Reparation to you, that the Publick had (after your contract, which was made for fifteen Score) alter'd the denomination of Score, and applyed it to sixteen instead of twenty. Examine it, and you will find this just the Case, and the Loss proportionable in them both: That is, a real Loss of 20 per Cent.” (Locke, 1697)

Locke is right to claim that it is senseless to say that 240 cacao-nuts have now the same worth as 300 before at the same time that cacao-nut are the standard of price. The statement that the value of the cacao-nuts has changed in time presupposes a prior standard of value beyond the cacao-nuts. But there cannot be any standard of price beyond the standard of price. We could say that the standard of price is the ultimate standard of price, which means that the standard of price does not have price in some ulterior standard of price. If it had, that ulterior commodity would be the true standard of price. If the cacao-nut is selected as the measure of value (and the only way to do this is to declare the cacao-nut to be the standard of price) 300 cacao-nuts must always be $20 \%$ more money than 240 cacao-nuts, no matter how much the value of cacao-nuts in relation to gold or cinnamon might change. On cannot appeal here either to the marginal utility theory of value and say that the marginal utility of the cacao-nuts falls as the receiver of the payment gets cacao-nuts and his preference for cacao-nuts remains the same. Cacao nuts do not count here as use values, but as representatives of exchange value. The receiver of cacao nuts in payment is not meant to consume them; they do not represent food, but money, subjects of exchange value.

In my opinion, Locke strikes the right note when he says that two ounces of silver will always represent double the quantity of money than one ounce of silver because the value of two ounces of silver is double the value of one ounce of silver, regardless of the variation in the value of silver in relation to other commodities. Equal quantities of silver always represent the same money; this is the ground on which Locke attacks the thesis of Lowndes that the debasement of the English silver coins according 
to the market bullion price just acknowledges the rise in value of silver. Silver cannot rise in value if silver is the measure of value, answers Locke; or better: the value of silver in relation to other commodities is irrelevant for its role of measure of value as standard of price. Silver is the measure of value in so far as 2 ounces of silver represent double amount of silver than 1 ounce. This is why a rise in the value of silver (in relation to the rest of commodities, of course) although it changes the $(n-1)$ relations between silver and each of the other commodities, does not alter the relations between the $(n-1)$ quantities of silver that are related to each commodity as its silver or money price. In a word: the changes in the value of the measure of value are irrelevant for the determination of relative prices, and value exists only as relative price.

"Hence it is evident, that an equal quantity of Silver is always of equal value to an equal quantity of Silver.” (Locke, 1697)

Locke is right here. The value of silver, as that of any commodity, is variable. In measuring value according to a standard of price, what matters is that equal amounts of silver will always bear the same relation or proportion, which is $1: 1$. No matter what the value of silver in terms of any other commodity may be, it will always remain true that the value of two ounces of silver is double the value of one ounce of silver. It is in this sense that silver is the standard of price, and it is in this sense that silver is measure of value. We can only measure value as price, which means that silver is measure of value in the sense that it is standard of price. For a standard of price to be a good standard, what counts is the equality of its parts, that every silver coin contains exactly the same amount of silver of the same quality. Locke, unlike Lowndes, is aware of this the distinction between the two functions of silver as measure of value and as means of exchange and, unlike Lowndes, does not mix them up:

"Silver (...) is the thing bargain'd for, as well as the measure of the bargain; and in Commerce passes from the buyer to the seller, as being in such a quantity equivalent to the thing sold: And so it not only measures the value of the Commodity it is apply'd to, but is given in Exchange for it, as of equal value. But this it does, (as is visible) only by its quantity, and nothing else. For it must be remembered, that Silver is the Instrument as well as Measure of Commerce, and is given in exchange for the things Traded for." (Locke, 1697)

That silver is chosen as the standard of price does not imply that the debts measured in silver are to discharged by silver itself. Also, the fact that silver may be the 
general instrument of trade does not imply that debts have to be estimated in silver. This is important in so far as it has to do with inconvertibility. The substitution of inconvertible paper for gold in trade does not mean anything as to the elimination of gold from its role of standard of price, though it dispenses with gold as means of payment and, as such, represents a general saving for the whole of the economy. Thus, the substitution of inconvertible paper for gold does not lead to any emancipation of "real economic relations" from money or from gold.

Marx puts the same idea as follows, and introduces a further distinction on the mater of measure of value that makes clearer the basic idea correctly hinted at by Locke. This further distinction leaves aside the role of means of payment and concerned the relation between the measure of value and is between value and price:

"As measure of Value, and as standard of price, money has two entirely distinct functions to perform. It is the measure of value inasmuch as it is the socially recognised incarnation of human labour; it is the standard of price inasmuch as it is a fixed weight of metal. As the measure of value it serves to convert the values of all the manifold commodities into prices, into imaginary quantities of gold; as the standard of price it measures those quantities of gold. The measure of values measures commodities considered as values; the standard of price measures, on the contrary, quantities of gold by a unit quantity of gold, not the value of one quantity of gold by the weight of another. In order to make gold a standard of price, a certain weight must be fixed upon as the unit. In this case, as in all cases of measuring quantities of the same denomination, the establishment of an unvarying unit of measure is all-important. Hence, the less the unit is subject to variation, so much the better does the standard of price fulfil its office. But only in so far as it is itself a product of labour, and, therefore, potentially variable in value, can gold serve as a measure of value.” (Marx, 1867, 70)

\section{Lowndes' Two Theories On the "Value of Money"}

Locke attacks the views of Lowndes on the re-distributive neutrality of his plan of debasement by attacking the theory of the nominal standard of money. In so doing, he draws a clear (and, in my opinion, correct) distinction between the standard of price and the means of payment, that is, between money as measure of value and money as means of circulation. Once silver has been settled as the standard of price, silver remains the standard of price independently of the extent to which silver may be substituted for representatives in actual circulation. Locke attacks with all his dialectical artillery the basic principle of Lowndes that the excess of the market price of bullion over the mint-parity shows that the value of silver had risen in England. The essence of 
Locke's attack to this principle is that it is senseless to say that the value of silver has changed when silver itself is the standard of price. To explain the excess of the market price of silver above the mint-parity as the consequence of as rise in the value of silver in terms of silver amounts to offering nonsense in place of an explanation and provides no theoretical basis for any course of action.

It was a fact that the market price of silver was consistently higher than the mint-parity for a period of time. About this fact there is no debate. Lowndes intended to show that this fact was the empirical consequence of another (empirical) fact, which was the rise in the value of silver. Locke replied that this second fact does not exist, that it simply is meaningless language. Seemingly, in an attempt to account for the (in his opinion) two facts observed, Lowndes introduces the theoretical principle that the unit of money is a unit of value. This principle does not receive any support from the two facts just mentioned, nor do they contradict it. Indeed, and pace the empiricists, operationalists and the like, facts are unable to establish any theoretical principle. On the theoretical principle that a monetary name is the name of a definite quantity of exchange value (and not of silver) Lowndes concludes that the purchasing power of money remains constant as long as the monetary names of the values of the commodities remain constant. From this principle, Lowndes intends to show that a reduction in the silver content of the coins regulated by the excess of the market price of silver over the mint-parity would not involve any re-distribution of wealth.

In my opinion, there are in Lowndes (or perhaps around Lowndes) two different and conflicting conceptions of the value of money. Lowndes holds at times, that the value of money is determined by the names of the coins, and not by the silver content of the coins. At other times, however, he maintains that the value of money is determined by the value of the silver contained in the coins. On this premise, he holds that the meanings of the names of the coins change as the value of the silver contained in them changes. To put it otherwise: Lowndes' apology of his plan of debasement contains two conflicting theories of the value of money. On the one hand, Lowndes maintains that the monetary names are names of definite quantities of exchange value; it is on this premise that he argues that the changes in the silver content of the coins and even the changes in the value of that silver content are irrelevant for the determination of the purchasing power of the coins. In this first theory, all that counts in money is the 
monetary names. As long as one receives the same amount of coins with an invariable stamp upon them, one is always receiving the same amount of money. If the name of money remains the same, money remains the same. This means that the amount of silver contained in each crown coin is irrelevant to determine its purchasing power; also, it means that the value of the silver that the crown may contain is equally irrelevant to determine the purchasing power of the crown coin. When Lowndes goes this way, he sounds like an early prophet of inconvertible paper currency and seems to be on the verge of proposing the printing of crown marks on pieces of paper instead of on pieces of silver.

This view has an interesting theoretical implication that I deem worth stressing. Ultimately, the thesis that the monetary names are the names of the value of commodities implies the abolition of money as measure of value. If the monetary names are names of the values of commodities, we have suppressed the relation of the value of commodities to money. If "crown" is the name of the exchange value of a quarter of wheat, we go directly to the value of wheat (the commodity) without passing through money. It would not make any sense to ask about the correspondence or adequacy of the value of money (of a silver crown, if you wish) to the value of a quarter of wheat. If we impose names directly on the value of commodities without the intermediation of silver, it logically follows that it would pay to withdraw silver from the sphere of payments altogether; ultimately, we have abolished money and deal directly with the value of commodities. I would like to remind the reader that, in Lowndes, the excess of the market price of silver bullion over the official mint-parity is never explained as the result of the loss of silver of the coins; this explanation is totally Locke's. In Lowndes, whatever the loss in the silver content of the coins might be, the excess of the market price of silver over the mint-parity unequivocally shows that the value of silver has risen.

However, Lowndes' view that the silver content of the coins has to be changed in inverse proportion to the excess of the market price of silver over the official mintparity implies that the value of money (the purchasing power of the coins) is determined not by the name stamped upon them, as in the first theory just laid down, but by the value of the silver contained in them. Note well: the purchasing power of the crown coins, for instance, is determined not by the amount of silver (actual or hypothetically) 
contained in the crowns, but by the value of the silver of which the crown coins are made. When sticking to this second theory about the value of money, Lowndes is denying the previous priority that he gave to the monetary names or marks stamped upon the coins (the logical end of which is an inconvertible paper currency and the total displacement of the precious metals from circulation) and, in conflict with it, he says that the silver content of the coins is crucial, not as such, but its value -obviously, a metallic coin that contains no metal is a self-contradiction. This second theory sets a limit to the debasement of the coins, namely, the market price of silver. In the first theory there is no such limit to the debasement of the coins or, rather, the limit is the displacement of the precious metals from circulation.

The conflict between Lowndes' two conceptions of the value of money can be shown by comparing three terms, namely, a crown of silver, a crown of copper and a crown of paper. According to Lowndes' first theory, the purchasing power of the three types of money is the same because the name on them is the same. On the contrary, according to his second theory, the value of the silver crown is determined by the value of the silver contained in it. As silver is more valuable than copper, a crown of copper has less value than a crown of silver and a crown of paper has less value than a crown of copper. It also follows that the value of the paper crown is but the value of the paper on which the crown sign is printed. The underlying principle is that the value of the three species of money is unequal even though the names are equal. In this second theory of Lowndes about the value of money, in opposition to the first, the door to an inconvertible paper currency is closed, because if there is no metal, it is absurd to base the value of coins on the value of a metal that simply is not there. An inconvertible paper currency is discarded and it is debatable whether there remains room for a convertible paper currency.

Lowndes' view that the English stock of silver had to be recoined according to the high price of silver bullion because the excess of the market price of silver over the mint-parity showed that the value of silver had risen, is based on his second theory of the value of money rather than on the first. The contention that such a debasement would not have any re-distributive effect of wealth is, however, another matter. From which of the two theories of Lowndes does it follow? Before taking up this question, let me point out that, ultimately, the reason why the silver content of the English silver 
coins had to be reduced by the same proportion as the proportion by which the market price of silver bullion was above the mint-parity was that the quantity of value that operates as unit of value (of money, would say Lowndes), as standard of price, is to be kept constant. This requires a constant variation of the mint-parity in inverse proportion to the variations of the market value of silver bullion: the silver content of a crown is to be cut when the market price of silver rises above the current mint-parity (and by the same proportion) and increased when it falls below the mint-parity (again, by the same proportion, of course). With such constant adjustment, the value of money would be kept constant because the name "crown" would always denote the same quantity of exchange value. There is more money in an ounce of silver when the value of silver rises and less when it falls.

The question arises immediately: if all the theory that the justification of the plan of debasement needs is provided by the second theory, what does Lowndes introduce the first theory for? For what I see, my hypothesis is that Lowndes calls in his first theory about the value of money in order to defend that the debasement according to the high price of bullion does not imply any re-distribution of wealth. The second theory invites the debasement in; the first exonerates it of unpalatable re-distributive effects. However, according to Kleer (see Kleer, 2004), Lowndes did indeed believe that his debasement would cause re-distributive effects, despite his contrary public pronouncements. According to Kleer, Lowndes believed that his debasement would benefit the class that Lowndes intended to benefit (at the expense of the rest of society), which was the financiers of the English crown, then in desperate need of money to fight on the Succession War on the Continent. According to Kleer, Lowndes was a cunning statesman whose aim was to deceive the Parliament into the belief that a debasement of the English silver coins according to the excess of the market price of silver over the mint-parity would be re-distributionally neutral. Under the pretext of restring order to the English silver currency, the secret purpose of Lowndes was to make a present to his friends at the expense of the rest of the nation. According to Kleer, Lowndes believed that the financiers had large stocks of heavy silver coins. A debasement of the English silver coins would automatically multiply the amount of money in the hands of that class of people, as they owe large stocks of unworn and unclipped coins: all they have to do is melt the heavy coins and recoin the silver at the new high mint-parity. Independently of Kleer, I dare to suggest that even Lowndes' references to an 
adjustment to the enhanced value of silver are a smokescreen and Lowndes did never seriously think of any "adjustment". The story about the need to adjust the metal content of the coins to the increased value of silver simply provides an appearance of "technical necessity" to an essentially political maneuvre. Actually, any debasement would have done for Lowndes; only, the larger, the better, for the greater would be the gain of the financiers at the expense of the rest of the nation.

Lowndes introduces his first theory about the value of money in the course of his defense of his plan of debasement (which is based on his second theory) only in order to reject the objection of Locke that such a debasement (and any debasement in general, no matter whether in accordance or variance with the divergence of the market price of silver bullion from the mint-parity) necessarily involves an arbitrary redistribution of wealth.

Locke is right to reply to Lowndes: one cannot say that the debasement of the English shilling is the consequence of the rise in the purchasing power of silver against the monetary name shilling, because "shilling" is just the name of a definite amount of silver and not the name of the value of that silver (or of any amount of value). The relation between silver and shilling is that of convention, not of value. Shilling is the name of one of the many possible standards of price, that is, the name of a particular amount of silver, and silver is the standard of price. The view that the debasement of the silver coins represents a rise in the value of silver, or more in general, a rise in the value of the standard of price, implies that the debasement of the currency implies a rise in the value of the standard of price in relation to the standard of price itself, which is a "contradictio in adjecto".

Apart from his political and strategic interests, from a theoretical standpoint Lowndes confuses the possibility of dispensing with silver in actual circulation with the function of silver as standard of price. The fact that the creditor may accept payment in a representative of silver, which may be a coin with less silver, or a coin of bronze, or a piece of paper, does not mean anything for the role of silver as standard of price. The fact that the precious metals may be removed altogether from actual circulation does not mean anything as to the "stability" of the standard of price. 


\section{Steuart's Criticism of Locke' Position About the Beneficiaries of the Planned Debasement}

First, Steuart agrees with Locke against Lowndes that the debasement according to the high price of bullion cannot be defended on the basis of a rise in the value of the standard of price. He aggress with Locke that, once silver has been set as the standard of price, to say that the excess of the value of silver bullion over the mintparity shows that the value of silver has risen is just nonsense, because, as Locke correctly noted, it amounts to saying that the value of silver in terms of silver has risen. Secondly, Steuart joins forces with Locke to claim against Lowndes that any debasement entails a re-distribution of wealth, even a debasement according to the market price of bullion. However, he disagrees with Locke as to the beneficiaries of the automatic re-distribution of wealth that a debasement implies. According to Steuart, Locke is right to hold that the debasement takes wealth (money) away from the class of creditors and landlords, but wrong to say that this money ends up in the hands of those who possess heavy coins. Steuart points out against Locke that the latter view amounts to the admission of the thesis of Lowndes that the debasement (according to the high price of bullion) is not inflationary. The right conclusion that Locke should have deduced from his correct premises, is that the wealth that the debasement takes away from the creditors and the landlords ends up in the hands of the debtors.

Steuart looks into the debate between Lowndes and Locke in order to illustrate his following thesis:

"Every variation upon the intrinsic value of the money-unit has the effect of benefiting the class of creditors, at the expence of debtors, or vice versa." (Steuart, 1767 [1966], 40)

By "intrinsic value of the money-unit" Steuart means the quantity of precious metal contained by convention in the money-unit. According to his thesis, the debasement of the currency is relevant only as far as debt relations are concerned. He summarizes the polemic between Locke and Lowndes as follows:

"In 1695 a proposal was made to the government of England, to diminish the value of the pound sterling by 20 per cent by making a new coinage of all the silver, and by making every shilling 1/5 lighter than before. The author of this project (Mr Lowndes) having given his scheme to the public, was answered by Mr Locke, that this debasing of the value of the money-unit was effectually defrauding all the landed interest of 20 per cent of their rents. Lowndes replied, that silver was augmented 20 per cent in 
its value, and that therefore the pound sterling, though reduced 20 per cent in its weight of pure silver, was still as valuable as before. This proposition Mr Locke exploded with the most solid reasoning, and indeed nothing could be more absurd, than to affirm, that silver had risen in value with respect to itself." (Steuart, 1767 [1966], 41)

Thus, Steuart agrees with Locke that the excess of the market price of silver over the official mint-parity cannot be viewed, as Lowndes does, as a revaluation of silver. We already saw that Locke, against Lowndes, explained the excess of the market price of silver over the mint-parity as the manifestation of the loss of content of the silver coins. Steuart agrees with Locke that it is absurd to say that the value of silver has risen when silver itself is the measure of value or standard of price.

"But though Mr Locke felt that all the landed interest, and all those who were creditors in permanent contracts, must lose 20 per cent by Mr Lowndes's scheme, yet he did not perceive (which is very wonderful) that the debtors in these contracts must gain. This led him to advance a very extraordinary proposition, which abundantly proves that the interests of debtors and creditors, which are now become of the utmost consequence to be considered attentively by modern statesmen, were then but little attended to, and still less understood. (Steuart, 1767 [1966], 42; italics mine)

On what basis did Locke denied that debtors would gain what creditors lose with a debasement? Or should we say with an inflation?

"We find in the 46th page of Mr Locke's Farther Considerations concerning raising the value of Money, that Mr Lowndes had affirmed in support of his scheme, that this new money would pay as much debt, and buy as many commodities as the then money which was one fifth heavier." (Steuart, 1767 $[1966], 42)$

This implies that it was Lowndes' view that nominal prices would not rise as a consequence of the debasement; all that will happen is that silver prices will fall by one fifth, but shilling prices would remain the same. Locke, on the contrary, held that nominal prices will rise by one fifth and that silver prices will stay the same. Lowndes held that his debasement will not trigger any inflation of monetary prices: nominal or "coin" prices will remain constant after the debasement and, therefore, relative prices will also remain constant. On the contrary, silver prices should fall (though uniformly) as the value of silver, according to Lowndes, has risen. Steuart clearly disagrees with these views of Lowndes and agrees with Locke that the debasement will raise by one fifth nominal or coin prices so as to leave silver prices constant: it will raise "coin" prices by the full proportion of the diminution of the official metal content of the coins. 
On this debate, Steuart takes sides with Locke: after the debasement, more lighter coins will be given for the same goods so as to maintain constant the amount of silver given in payment.

It is clear, however, that a $20 \%$ debasement of the silver shilling produces 120 coins of one shilling where there were 100. 120 coins after the debasement contain exactly the same amount of silver as 100 coins before the debasement. Lowndes would have to say that the owner of heavy coins sees his money increased or multiplied by $20 \%$ as a result of the debasement. Lowndes would have to say that the owner of heavy coins, after the debasement, has the same silver, but more money; he has $20 \%$ more money because he has $20 \%$ more value (silver, according to Lowndes, has risen in value by $20 \%$, and the quantity of silver owned has not changed). The owner of heavy coins has $20 \%$ more shillings because he has $20 \%$ more value. How could Lowndes claim that the debasement, which multiplies the amount of money in the hands of the owners of heavy coins, does not have any redistributive effects? Neither Lowndes nor any of his enemies raise this question which, therefore, remains un-debated and unanswered.

Steuart agrees with Locke that Lowndes' debasement would not be neutral as far as the distribution of wealth is concerned. He agrees with Locke as to the losers, but disagrees as to the beneficiaries. We have seen that, according to Locke, the wealth lost by the landlords and money lenders will end up in the hands of those who happen to own heavy coins. Why? There is here a curious coincidence between Lowndes' secret aims and Locke's public declarations, as Locke claims that the possessors of heavy coins would be unjustly enriched by Lowndes' debasement because it will multiply the amount of money in their hands. Steuart replies to Locke that he is wring to arrive at this conclusion. Steuart claims that, in holding that the debasement will favor those who have heavy coins because it will multiply their money by one fifth, Locke implicitly conceding the theory of Lowndes that the excess of the market price of silver over the mint-parity shows that the same silver represents more money!

The reason is that, if one holds that, as a consequence of the debasement, nominal prices will rise by $20 \%$ so as to leave constant the amount of silver exchanged for goods, then to have heavy coins represents no advantage after the debasement. It would if Lowndes was right and coin prices remained constant. But if, as Locke contends, coin prices will rise by $20 \%$, the increase in the amount of coins for the 
holders of heavy coins, from, say, 100 to 120 , is exactly offset by the increment of the nominal price level, which, according to Locke, will be of $20 \%$ too. Those who posses heavy coins, my melting them and recoining the silver obtained according to the higher mint-parity, will get more coins, true, but this increase in the quantity of coins is exactly offset by the fall in the purchasing power of each coin (rise in nominal commodity prices). To hold that the possessors of heavy coins will be favored by the debasement because their money will be multiplied by $20 \%$ logically necessitates to admit the thesis of Lowndes that coin prices will not be affected by the debasement. Thus, Steuart correctly observes against Locke:

"If the authority of any man could prevail, where reason is dark, it would be that of Mr Locke; and had any other than such a person as Locke advanced such a doctrine, I should have taken no notice of it. Here this great man, through inadvertency, at once gives up the argument in favour of his antagonist, after having refuted him in the most solid manner: for if a man, who at that time had hoarded heavy money upon its being coined into pieces 1/5 lighter were to gain Mr Locke must agree with Mr Lowndes, that a light piece was as much worth as a heavy one." (Steuart, 1767 [1966], 43)

The one who is in the deeper trouble here is Lowndes, because, on what ground could he justify that his planned debasement would not benefit the holders of heavy coins and, therefore, that his debasement did not have any re-distributive effect? It is interesting that Locke does not raise this question against him. To defend the neutrality of his debasement, Lowndes would have to say that it is no gain for the owner of heavy coins to have his money multiplied by $20 \%$.Either one agrees with Locke and Steuart or there is no way to deny that the debasement represents a windfall gain for the holders of heavy coins. Unlike Locke, Steuart is coherent and claims that it is true that the owners of heavy coins will not benefit form the debasement because of the inflation that should ensue. Here is Steuarts correction of Locke:

"Those who had heavy money at that time locked up in their coffers, would gain no doubt, provided they were debtors (KO: my emphasis); because having, I shall suppose, borrowed 40001. sterling in heavy money, and having a like sum borrowed from their coffers, augmented to 50001 . by $\mathrm{Mr}$ Lowndes's plan, they might pay their debt of 40001 . and retain one thousand clear profit for themselves. But supposing them to have no debts, which way could they possibly gain by having heavy money, since the 5000 l. after the coinage, would have bought no more land, nor more of any commodities, than 40001. would have done before the coinage." (Steuart, 1767 [1966], 44)

Steuart, thus, concludes: 
"We may therefore safely conclude, that every diminution of the metals contained in the money-unit, must imply a loss to all creditors; and that in proportion to this loss, those who are debtors must gain.” (Steuart, 1767 [1966], 44)

Compare to Kleer, who accepts the view of Locke and ignores the criticism of Steuart to Locke:

"It certainly did not escape Locke's attention that raising the coin would amount to a massive handout to the financial community. He complained that the benefits would go to "those ... who have great Sums of weighty Money hoarded up by them. To those by the proposed change of our Money will be an increase of one fifth added to their Riches, paid out of the Pockets of the rest of the Nation. For what these men received [from their depositors] for Four Shillings, they will pay [out] again for Five". The gains to hoarders -bankers and tax collectors for the most part- would come mainly at the expense of the gentry, who were already carrying a disproportionately heavy burden.” (Kleer, 2004, 550-1)

According to this passage, Locke was defending the gentry against the hoarders (holders of heavy coins) whom Kleer identifies as the bankers and tax collectors. Kleer accepts the opinion of Locke, which Steuart criticizes as wrong, that Lowndes' debasement would benefit the holders of heavy coins, not the debtors. Besides, according to Marx, Locke did not aim at defending the gentry, but precisely, the bankers, to whom his scheme granted a re-distribution of wealth as long as it required the repayment of debts contracted in light shillings with heavy shillings.

Was Steuart right to pronounce wrong Locke's answer to the question about the advantages to the holders of heavy coins? Look at what Locke writes where he denounces that Lowndes' debasement will confiscate one fifth of the wealth of landlords and money lenders:

"No body else, but these Hoarders, can get a Farthing by this proposed change of our Coin; unless Men in Debt have Plate [KO: objects made of silver, not silver coins, I guess] by them, which they will Coin to pay their Debts. Those too, I must confess, will get One fifth by all the Plate of their own, which they shall Coin and pay Debts with; valuing their Plate at Bullion.” (Locke, 1697)

This seems to agree with Steuart, as here, the debtors see their debts cut by $20 \%$ as a consequence of the debasement of the coins! But the story continues and Locke qualifies this thesis and discards his basically correct intuition on the ground of practical considerations: 
"But if they shall consider the fashion of their Plate, what that cost when they bought it, and the fashion that new Plate will cost them, if they intend ever to have Plate again, they will find this One fifth seeming present profit in Coining their Plate to pay their Debts, amount to little or nothing at all. No body then but the Hoarders will get by this Twenty per Cent [KO: because the debasement multiplies the amount of coins of their property, and not because they have to repay heavy coin debts in light coins]. And I challenge any one to shew how any body else (but that little in the case of Plate Coin'd to pay Debts) shall get a Farthing by it." (Locke, 1697)

As the melting the objects of silver and the coining them into new coins involves a cost comparable to the diminution of the debts, the debtors who possess of objects of silver will not be substantially benefited by Lowndes' debasement. Locke goes on:

"It seems to promise fairest to the Debtors; but to them too it will amount to nothing. For he that takes up Money to pay his Debts, will receive this new Money, and pay it again at the same rate he received it, just as he does now our present Coin, without any profit at all.” (Locke, 1697)

This proves that the debtor will not gain in a future debt taken in debased coins, but fails to prove that he does not gain when he has to repay a debt taken in heavy coins with debased coins. Who gets what the debasement takes away from the holders of assets? Locke's, answer is: the holders of the corresponding liabilities do not get it. The whole gain is for those who hold silver bullion. Why? Because their money is multiplied by the debasement. According to Steuart, this answer is wrong. The thesis that the holders of silver bullion gain because the same silver represents more money after the debasement implicitly accepts the thesis of Lowndes that was to be rejected. Steuart answers: the holders of bullion gain what the holders of assets lose in so far as the holders of silver bullion are debtors, that is, in so far as they hold the corresponding liabilities, not in so far as they hold cash balances, because relative prices stay the same. I conclude, therefore, that Steuart is right in his criticism of Locke.

\section{Marx}

Marx comments on the debate between Lowndes and Locke in order to refute the theory of the "nominal standard of money", which is the thesis that the monetary names stand for definite quantities of value; to put it otherwise, the thesis that the unit of money is a unit of value. In the "Contribution", which is where Marx expressly comments on the Lowndes-Locke debate, he attributes the theory of the nominal 
standard of money to Lowndes, Steuart (!), Berkeley and Attwood. Marx supports Locke's refutation of Lowndes' version of the theory, though, most interestingly, he notes that Locke himself embraced this theory in the places where he claimed that the loans granted in light coins should be repaid in heavy coins because what counts is the nominal amount of money. We shall presently look at that.

Marx explains that the theory of the nominal standard of value arises from the confusion of the function of money as measure of value with its function of standard of price. The variability of the value of the commodity selected as measure of value does not preclude its function of standard of price, because the commodity that acts as standard of price does so in virtue of the relation between different physical portions of that commodity; this is but the principle that we already saw in Locke that silver acts as measure of value as long as the value of two ounces of silver will always be double the value of one ounce, whatever the value of silver in relation to the rest of commodities might be. Thus, the standard of price is a determinate amount of gold or silver, not the value of a determinate amount of gold and silver. As Locke correctly noted, says Marx, the very notion of "price of the standard of price" or of "value of the measure of value" is nonsense.

"The fact that commodities are only nominally converted in the form of prices into gold and hence gold is only nominally [KO: it would be better "ideally"] transformed into money led to the doctrine of the nominal standard of money. Because only imaginary gold or silver, i.e., gold and silver merely as money of account, is used in the determination of prices, it was asserted that the terms pound, shilling, pence, thaler, franc, etc., denote ideal particles of value but not weights of gold or silver or any form of materialised labour.” (Marx, 1970, 76)

The theory of the "nominal standard of money" implies that the standard of price is a standard of value, or, in more updated terminology, that the numeraire is a unit of value. For Marx, this is a major mistake: a monetary name is not the name of a determinate amount of value, of a determinate quantum of exchange value, but $a$ standard of price, the name of a definite quantum not of value, but of a metal; more in general, of some particular commodity which has value but is not value as such. The variations in the value of the commodity that serves as standard of price in relation to the rest of the commodities do not "falsify" prices: the reason is that for any change in the value of, say, silver, in relation to each of the other commodities, the silver relative prices of the commodities other than silver remain the same, and exchange value is 
precisely, a relation. The relation between constant quantities of silver, whatever the value of silver in relation to the rest of the commodities, is the objective expression of the exchange value of commodities. This means that the variations in the value of silver do not require any change in the amount of silver referred by the monetary names. Such a change could not be defended on the basis of "monetary stability", because money is not value already that is, it is not value as such, but a commodity that has value as an adjective property.

Interestingly, and in contrast to the standard literature, Marx poses the debate between Lowndes and Locke in relation to the repayment of the debts already taken by the English government, that is, in relation to the repayment of the English public debt, rather than in relation to a strategy to attract more loans to finance the expenses of the English crown, as is the case in the standard literature. As we have seen, it was fairly well known that the Treasury of England had been financing itself with debts taken in light shillings. Were these debts to be repaid in light or in heavy coins once it became apparent that the condition of English silver coins was appalling?

"The government debts had been contracted in light shillings, were they to be repaid in coins of standard weight?" (Marx, 1970, 77)

If Lowndes' plan was not followed and the English stock of silver was recoined at the official mint-parity, as Locke contended it should, the English Treasury would have to repay in heavy coins a huge amount of debts taken in light coins. It would be hardly surprising to learn that Lowndes, as secretary of the Treasury, was not very happy about this prospect.

"Instead of saying pay back 4 ounces of silver for every 5 ounces you received nominally but which contained in fact only 4 ounces of silver, he [KO: Lowndes] said, on the contrary, pay back nominally 5 ounces but reduce their metal content to 4 ounces and call the amount you hitherto called 4/5 of a shilling a shilling. Lowndes's action, therefore, was in reality based on the metal content, whereas in theory he stuck to the name of account." (Marx, 1970, 77)

Lowndes did not choose the most obvious way, which was to make official that, as was well known, the government debts had been contracted not in heavy but in light shillings. Even the lenders themselves to the English Treasury knew only too well that they had lent it light coins. If, in fact, the English government had actually received 
light coins, let its creditors be repaid in light coins; this would be the simple but logical path that Lowndes, surely for political reasons, chose not to go. If the creditor protests that he is receiving 4 ounces for every 5 he lent, it is easy to dismiss his claim answering that, in fact, he lent out 4 ounces, not 5 . However, the fact that Lowndes did not chose to go this arithmetically obvious way does not mean by any means that he was prepared to repay loans taken in light coins in heavy coins. His plan to repay the loans taken in light coins with light coins was the somewhat more complicated of recoining the silver of England and debase it in accordance with the high market price of silver bullion. The arrangement that Lowndes designed to avoid a premium for the English financial aristocracy at the expense of the Treasury was that the mint acknowledge the loss in metal of the English silver coins and set the mint-parity in accordance with the current higher value of silver bullion.

The thrust of Lowndes' project was, therefore, to call now 5 ounces what previously was called 4 ounces. The creditor is paid back 5 under the name of 4 , which would accord with the reality that he lent out 4 under the name of 5 . This means that, in actual fact, Lowndes was taken a quantity of money to be a quantity of silver, regardless the value of that silver or of the signs stamped upon the coins, that is, regardless the name given to a determinate amount of silver. On this account, Marx' presentation is revealing, as it shows that Lowndes was in fact Lockean when it came to the repayment of the outstanding English pubic debt! The theory of the value of money that Locke launched against Lowndes' apology of debasement was but the theory that Lowndes was actually embracing in order to ensure the repayment of debts contracted in light coins with light coins: there are equals amount of money where there are equal amounts of silver, regardless that value of silver in relation to the rest of commodities and the names given to the fractions of silver. This is what Marx is saying when he writes that "Lowndes' action was based on the metal content" as far as his plan to acknowledge the actual metallic content of the coins.

“His opponents [KO: of Lowndes' plan] on the other hand, who simply clung to the name of account and therefore declared that a shilling of standard weight was identical with a shilling which was 25 to 50 per cent lighter, claimed to be adhering to the metal content. John Locke (...) took up Lowndes's challenge. John Locke won the day and money borrowed in guineas containing 10 to 14 shillings was repaid in guineas of 20 shillings.” (Marx, 1970, 77) 
Just as Lowndes was in fact Lockean in relation to the mechanism of repayment of the outstanding English public debt, Locke was likewise Lowndesian in relation to that matter, and opposed the debasement put forward by Lowndes on the theory of the nominal standard of money! Ultimately, the English stock of silver was recoined, but not debased as Locke proposed against Lowndes. This means that the loans in light coins that the English financial aristocracy had made to the Treasury were to be paid back (together with interest, of course) in heavy coins, which implies a massive re-distribution of wealth towards the English financial aristocracy, a redistribution that Lowndes tried to avoid and Locke defended. Marx suggests that Locke was fully aware of this "re-distributive" effect. Kleer provides an interesting clue when he recalls us that Locke had to escape to Holland from London's goldsmiths in order to save his life; he quotes a letter of some Pawling to Locke where Pawling says:

"Truly 'twas time for you to be gon, for you attempted the ruine of their Diana and put a stop to that craft by which such K[naves] have got their gain.” (Pawling to Locke, quoted in Kleer, 2004, 552)

For those who might not remember the passage of the New Testament referred to by Pawling:

“The reference is to Acts 19:23-41. Two of Paul's disciples were almost killed at Ephesus by an angry mob stirred up by silversmiths specializing in shrines of the goddess Diana -whose divinity Paul had called into question." (Kleer, 2004, 552)

This suggests that, in the time around the Great Recoinage of 1696, in addition to the conflicts of the English Tresaury with its lenders, there was a strong conflict between the goldsmiths and the bankers, between the old usury establishment and the then emerging British banking industry. Marx sees in the Great Recoinage of 1696 a triumph of the young English banking industry against the old usurers (and against the rest of the English nation). The picture that emerges is one in which Lowndes tries to defend the interests of the English Treasury from both the banks and the goldsmiths, as Locke decidedly supports the young English banking industry as against the old usury. Marx knew the power of the usurers who tried to chase Locke; in a footnote to vol. 3 chapter 36 of "Capital", he quotes from English authors of the time:

"The rich goldsmith" (the precursor of the banker), "for example, made Charles II of England pay twenty and thirty per cent for accommodation. A business so profitable, induced the goldsmith 'more and more to become lender to the King, to anticipate all the revenue, to take every grant of Parliament 
into pawn as soon as it was given; also to outvie each other in buying and taking to pawn bills, orders, and tallies, so that, in effect, all the revenue passed through their hands'." (John Francis, History of the Bank of England, London, 1848, I, p.31.) "The erection of a bank had been suggested several times before that. It was at last a necessity" (1. c., p. 38). "The bank was a necessity for the government itself, sucked dry by usurers, in order to obtain money at a reasonable rate, on the security of parliamentary grants.” (1. c., pp. 59, 60).” (Marx, 1991, 737n)

Returning to the "Contribution", it is to be noted that Marx accepts the final diagnosis of Sir James Steuart:

"Sir James Steuart gives the following ironical summary of this operation: “...the state gained considerably upon the score of taxes, as well as the creditors upon their capitals and interest; and the nation, which was the principal loser, was pleased, because their standard" (the standard of their own value) "was not debased"." (Marx, 1970, 77)

The State gained "upon the score of taxes" because, after the recoinage at the old mint-parity, taxes were paid in full-weight money rather than in clipped money, as before. In other words: after the Recoinage at the old mint-parity, the tax payers had to give the State more silver under the same monetary name to cancel their tax debts which represented an advantage for the Treasury and a valuable means to better carry the burden of the repayment of the debts taken in light coins with heavy coins. The big loser was the class of debtors (which is the class that Steuart seems to have in mind when speaking of "the nation": those who are neither bankers nor the government), as the recoinage led them to having to repay full-weight coins for debts contracted in clipped coins.

The inversion of the relative positions of Lowndes and Locke at some time of the debate is one of the most interesting aspects of Marx' commentary of this episode, and it is something that I have not seen in the standard literature on the debate. In saying that the creditors have to have their loans repaid with heavy coins instead of with light coins, Locke is implicitly embracing the principle of Lowndes that the value of money is determined by the monetary names! After all, all the argument of Locke is that the creditors lent a definite number of shillings. They are to be paid back in heavy shillings because law is to be complied with, despite the fact that they lent out light shillings, simply because they lent a determinate amount of shillings, and a shilling is always a shilling, independently of its metal content. According to Marx, Locke rejects the theory of the nominal standard of money in so far as the debasement of the English 
silver coins is concerned, but he embraces it in so far as the estimation of the English State debts is concerned.

Marx extracts interesting lessons from the debate:

"The rate at which a token of value -whether it consists of paper or bogus gold and silver is quite irrelevant- can take the place of definite quantities of gold and silver calculated according to the mint-price depends on the number of tokens in circulation and by no means on the material of which they are made." (Marx, 1970, 78)

This would be the case of the worn silver coins.

"The difficulty in grasping this relation is due to the fact that the two functions of money -as a standard of value and as medium of circulation- are governed not only by conflicting laws, but by laws which appear to be at variance with the antithetical features of the two functions." (Marx, 1970, 78)

\section{Marx develops this idea:}

“As regards its function as a standard of value, when money serves solely as money of account and gold merely as nominal gold, it is the physical material used which is the crucial factor. Exchangevalues expressed in terms of silver, or as silver prices, look of course quite different from exchangevalues expressed in terms of gold, or as gold prices. On the other hand, when it functions as a medium of circulation, when money is not just imaginary but must be present as a real thing side by side with other commodities, its material is irrelevant and its quantity becomes the crucial factor. Although whether it is a pound of gold, of silver or of copper is decisive for the standard measure, mere number makes the coin an adequate embodiment of any of these standard measures, quite irrespective of its own material. But it is at variance with common sense that in the case of purely imaginary money everything should depend on the physical substance, whereas in the case of the corporeal coin everything should depend on a numerical relation that is nominal." (Marx, 1970, 120-1)

The following criticism of Marx to Fullarton in the first volume of "Capital", allowing for the different institutional circumstances, fits perfectly in the LowndesLocke debate:

"The following passage from Fullarton shows the want of clearness on the part of even the best writers on money, in their comprehension of its various functions: "That, as far as concerns our domestic exchanges, all the monetary functions which are usually performed by gold and silver coins, may be performed as effectually by a circulation of inconvertible notes paying no value but that fictitious and conventional value they derive from the law is a fact which admits, I conceive, of no denial. Value of this description may be made to answer all the purposes of intrinsic value, and supersede even the 
necessity for a standard, provided only the quantity of issues be kept under due limitation." (Fullerton: "Regulation of Currencies", London, 1845, p. 21.) Because the commodity that serves as money is capable of being replaced in circulation by mere symbols of value, therefore its functions as a measure of value and a standard of prices are declared to be superfluous!” (Marx, 1971, 104n)

\section{CONCLUSIONS}

1) The theory of the nominal standard of money is the outcome of the confusion of the function of money as standard of price-measure of value with its function of means of payment. At some time of the discussion, both Lowndes and Locke fail to see the distinction between silver as standard of price from silver as medium of circulation. This is what leads to the thesis that the value of money is the amount of value referred to by the monetary names, which implies that the amount of silver contained in the silver coins is irrelevant for their ability to discharge debts. The grain of truth in this view is that the position of (a determinate amount of) silver as standard of price does not require silver to be actually present at the time of payment.

The standard of price need not be present at the actual exchanges. We might say with Marx that, by setting silver as the standard of price, we turn the rest of the commodities into silver in an ideal way. The introduction of monetary names, the printing of marks on the coins is simply a contrivance to avoid the trouble of weighing them and the trouble of assessing the purity of the silver contained in the coins. In particular, the coins do not discharge debts in virtue of their names, but in virtue of their silver content, as both authors acknowledge at some time of their debate.

Locke is closer to the truth than Lowndes when he notes that the value of silver as against each of the other commodities of the economy is irrelevant for the function of silver as standard of price. What constitutes silver as standard of price is the selection of particular quantity of silver as the unit of price, or in another way, that silver functions as standard of price in virtue of the proportion between the different quantities of silver that express the values of the rest of the commodities, but not the value of the standard quantity of silver in relation to each of the other commodities. Lowndes' theory of the nominal standard of money arises from the confusion of the standard of price with the means of circulation. 
2) Marx is right to stress the Lowndesian face of Locke and the Lockean face of Lowndes. On the whole, in the debate, one can find not only two conception of the value of money, as in the standard literature, but, at least, three: 1) the value of coins is determined by the quantity of silver contained in them;2) the value of coins is determined by the value of the silver contained in them and 3) the value of coins is determined by the names stamped upon them. For all I have seen in this debate, I would lend my support to the first conception.

3) Marx' contribution is extremely helpful to clear the political positions in the debate; he makes the picture much clearer and thereby helps to discern the theoretical arguments at stake, separated from the practical interests of the parties. There are references to Locke in the standard literature as a defender of "monetary stability". I have shown that those references need a good deal of qualification.

4 ) Steuart is right in criticizing the thesis of Locke that, in case of debasement, the wealth lost by the creditors is not redirected to the debtors, but to the holders of heavy coins. The only way to justify this is to hold that a debasement does not trigger an equivalent inflation, but this is a thesis that Locke explicitly denies.

\section{REFERENCES}

Appleby, Joyce Oldham. 1978. Economic Thought and Ideology in Seventeenth-Century England. Princeton: Princeton University Press.

Brewer, John. 1988. The Sinews of Power: War, Money, and the English State, 16881783. Cambridge: Harvard University Press.

Challis. Christopher E. 1992. Lord Hastings to the Great Silver Recoinage. In $A$ New History of the English Mint. edited by C. E. Challis, 179-397. Cambridge: Cambridge University Press.

Coxe, William, ed. 1821. Private und Original Correspondence of Charles Talbot, Duke of Shrewsbury, with King William. London: Longman, Hurst, Rees, Orme \& Brown.

Davison, Lee, and Tim Keirn. 1988. John Locke, Edward Clarke, and the 1696 Guineas Legislation. Parliamentary History 7:228-40.

Beer, E. S., ed. 1979. The Correspondence of John Locke. Vol. 5. Letters Nos. 17022198. Oxford: Clarendon Press.

De Lozanne Jefferies, Claudia. 2007. Monetary Theory and Monetary Policy in Castile 
during the First Half of the $17^{\text {th }}$ Century, paper presented at the $11^{\text {th }}$ ESHET Conference.

Denise, H. 1906. Des refontes des monnaies sous l'ancien regime. Gazette numismatique française 12:48-178, 393-405.

Desmedt, Ludovic. 2007a. Les fondements monetaires de la revolution financiere Anglaise: le tournant de 1696. In La monnaie dévoilée par ses crises. Ouvrage collectif sous la direction de Bruno Théret. Editions de l'E.H.E.S.S., à paraître 2007.

Desmedt, Ludovic. 2007b. Counteracting Counterfeiting. False Money As a Multidimensional Justice Issue in $16^{\text {th }}$ and $17^{\text {th }}$ Centuries Monetary Analysis, paper presented at the $11^{\text {th }}$ ESHET Conference.

EItis, Waller. 1995. John Locke, the Quantity Theory of Money, and the Establishment of a Sound Currency. In The Quantity Theory of Money: From Locke to Keynes and Friedman, edited by Mark Blaug. 4-26. Aldershot. U.K.: E. Elgar.

Fay, C. R. 1932-34. Locke versus Lowndes. Cambridge Historical Journal 4:143-55.

Feavearycar, Albert. 1963. The Pound Sterling: A History of -English Money. 2nd ed. Oxford: Clarendon Press.

[Gervaize, Isaac]. 1696. A Proposal for Amending the Silver Coins of England, and the Possibility of It, without Any Great Charge to the Nation: Demonstrated in Two Different Ways. London.

Hawtrey. R. G. 1927. Currency and Credit. 3rd ed. London: Longmans. Green \& Co.

Horsefield, John Keith. 1960. British Monetary Experiments. 1650-1710. Cambridge: Harvard University Press.

Hutchison, Terence W. 1988. Before Adam Smith: The Emergence of Political Economy, 1662-1776. Oxford: Blackwell.

Ito, Seiichiro. 2007. Continuity and Discontinuity - the Early Stage of the Land Bank Controversy, paper presented at the $11^{\text {th }}$ ESHET Conference.

Jones, D. W. 1988. War and Economy in the Age of William III and Marlborough. Oxford: Basil Blackwell.

Kelly. Patrick Hyde. 1991. Introduction to Locke on Money. Oxford: Clarendon Press.

Kleer, Richard. 2004. "The ruin of their Diana": Lowndes, Locke and the Bankers. History of Political Economy, 36:3, 533-56.

Li, Ming-Hsun. 1963. The Great Recoinage of 1696 to 1699. London: Weidenfeld and Nicolson. 
Locke, John. 1691. Some Considerations of the Consequences of the Lowering of Interest and the Raising the Value of Money

Locke, John. 1697. Further Considerations Concerning Raising the Value of Money, Wherein Mr. Lowndes's Arguments for it in his late Report concerning An Essay for the Amendment of Silver Coins, are particularly Examined.

Lowndes, William. 1695. Report Containing an Essay for the Amendment of the Silver Coins. In McCulloch, J.R. 1995. Classical Writings on Economics. Volume II. A Select Collection of Scarce and Valuable Tracts on Money. Pickering and Chatto, London.

Mayhew, Nicholas J. 2000. Sterling The History of a Currency. New York: John Wiley.

Marx, Karl. 1970. A Contribution to the Critique of Political Economy. Progress Publishers, Moscow.

Marx, Karl. 1971. Capital, volume I. George Allen and Unwin, London, England., England.

Marx, Karl. 1991. Capital, volume III. Penguin Classics. Harmondsworth, Middlessex, England.

McCusker, John J. 1978. Money and Exchange in Europe and America, 1600-1750: A Handbook. Chapel Hill: University of North Carolina Press.

Petty, William. (1682) 1695. Sir William Petty, His Quantulumquodque Concerning Money: To the Lord Marquess of'Halyfax, Anno 1682. London: Awnsham \& John Churchill.

Quinn, Stephen. 1996. Gold. Silver, and the Glorious Revolution: Arbitrage between Bills of Exchange and Bullion. Economic History Review, XLIX, 3 (1996), 473-90.

Sargent, Thomas, and Francois Velde. 2002. The Big Problem of Small Change. Princeton: Princeton University Press.

Schumpeter, Joseph Alois. 1954. History of Economic Analysis. Edited by E. B. Schumpeter. New York: Oxford University Press.

Steuart, Sir James (1767) 1966: An Inquiry into the Principles of Political Economy. Glasgow U. P.: Glasgow.

Vickers, Douglas. 1959. Studies in the Theory of Money. Philadelphia: Chillon. 